\title{
Література:
}

1. Котельницький Н.А. Іван Ілліч Петрункевич (1843-1928): життя та діяльність в Україні. Riga: GlobeEdit, 2019.197 р.

2. Котельницкий Н.А. Иван Ильич Петрункевич: жизнь и деятельность на Черниговщине. Историко - биографический очерк. М.: Летний сад, 2015. 124 с.

3. Доклад Комиссии Черниговского губернского земского собрания 1879 г. Мнения земских собраний о современном положении в России. Берлин, Типография Е. Бока,1883. С. 91-98.

4. Доклад Комиссии Черниговского губернского земского собрания 1879 г. Мнения земских собраний о современном положении в России. Берлин, Типография Е. Бока, 1883. С. 94-97.

5. Доклад Комиссии Черниговского губернского земского собрания 1879 г. Мнения земских собраний о современном положении в России. Берлин, Типография Е. Бока, 1883. С. 97-98.

DOI https://doi.org/10.30525/978-9934-588-91-4-14

\section{КОНЦЕПЦІї СВІТОВОЇ РОЛІ США В ОСТАННІЙ ТРЕТИНІ ХVIII СТ.: ІДЕЙНІ ВИТОКИ АМЕРИКАНСЬКОЇ ЗОВНІШНЬОЇ ПОЛІТИКИ}

\author{
Котляр О. А. \\ студентка магістратури I курсу історичного факультету \\ Київського національного університету імені Тараса Шевченка \\ м. Київ, Украӥна
}

В останній третині XVIII ст. відбулася кристалізація ідей глобального впливу США. Їх творці (у першу чергу, йдеться про батьківзасновників) спроектували концептуальні основи нової держави i збудували ії на особливих уявленнях про майбутню роль Сполучених Штатів у світі. Як писав А. Гамільтон, Америка була «Геркулесом у колисці», адже саме прагнення до величі та віра в особливу місію стали невід'ємною частиною американської свідомості. А. Сміт у 1776 р. так описував трансформації у Новому Світі: «Із власників магазинів, торговців, адвокатів вони стають державними діячами та законодавцями і зайняті у створенні нової форми правління для великої імперії, яка, постане і перетвориться на одну із найбільш могутніх та грізних, що будь-коли існували» [1, p. viii]. Подібні ідеї в Америці на той час ще не були оформлені у вигляді політичних або філософських концепцій, проте ідеологічне підгрунтя Американської революції, у значній мірі, 
базувалося на теоретичних принципах європейського Просвітництва у поєднанні із особливостями внутрішнього розвитку, що створило умови для їх практичного втілення у майбутньому.

Дослідження здійснено на основі джерел писемного типу. В роботі представлені актові джерела, серед яких найбільше залучені публічноправові документи (переважно - інавгураційні промови американських президентів Т. Джефферсона, Дж. Вашингтона та ін.), публіцистичні твори, що розкривають полемічні питання, а також джерела особистого походження (епістолярна спадщина Т. Джефферсона, Дж. Вашингтона, Дж. Медісона, А. Гамільтона). Дихотомічність останньої групи джерел, 3 одного боку, потребує більш критичного підходу, з іншого - забезпечує більш повну репрезентацію процесів та подій досліджуваного періоду. Історіографічні школи із даної проблематики на сьогодні не сформовані, однак значний внесок у ії розвиток зробили такі американські дослідники, як М. Склар, Р. Хендріксон, Дж. Геррінг, М. Геллерт. Оперуючи варіаціями термінів і понять, пов'язаними із формуванням особливостей американського національного етосу та характером політики держави в період ii становлення, необхідно враховувати методологічні особливості теми, пов'язані із проблемою визначення авторства і спадкоємності ідей американського лідерства.

Т. Джефферсон, один із архітекторів нової держави, був першим у США, хто у власній системі поглядів оскаржив пріоритетність зовнішньої політики над внутрішньою, характерну для Європи, називаючи ці ідеї протилежними людському прогресу та просвіті. Одночасно, особливістю його бачення Сполучених Штатів була їх подальша експансія - не лише територіальна, але й культурна, духовна, інтелектуальна. Цю ідею він уклав у поняття «Імперії свободи» («Empire of Liberty»), вперше згадане Т. Джефферсоном відносно американської держави. 3 одного боку, згаданий концепт не був новим на момент становлення США, адже свобода залишалася фундаментальним елементом процесу розвитку колишніх колоній, однак таке трактування їх сутності пізніше було органічно уплетено в матерію американської державності.

Т. Джефферсон прагнув побудувати новий тип держави, не схожий на інші відомі в історії, однак називав США саме імперією, адже свобода не може процвітати без розширення іiі простору. При цьому, американська імперія мала протистояти традиційним попередницям, які, постійно змінюючи геополітичну ситуацію в Новому Світі у XVIII ст., загрожували ідеалам та цінностям Америки. Якби свобода на північноамериканському континенті була знищена, республіканський експеримент не мав би жодного успіху, тому, згідно із поглядами T. Джефферсона, зростання «Імперії свободи» та американської республіки - тотожні поняття. 
В американській інтелектуальній історії свобода першочергово означала самоврядування, проте будувати імперію, в основі якої лежить самоврядування здається суттєвим протиріччям. Наразі на прикладі США ми маємо яскраве свідчення можливості такої практики. Поняття свободи та іiі трактування стало черговим концептом, який став одним із базових принципів визначення зовнішніх та внутрішніх пріоритетів США. Цей лейтмотив очевидно протежується у листі Т. Джефферсона до Дж. Кларка від 25 грудня 1780 р.: «... ми створимо для нашого Американського союзу бар'єр проти небезпечного розширення британської провінції Канада і приєднаємо до Імперії свободи велику та родючу країну, перетворимо небезпечних ворогів на цінних друзів» [2].

Схожу фразу третій президент США неодноразово згадував, посилаючись на обширні західні території континтенту, які, на його думку, мали бути доєднані до нової держави, заснованої на принципах свободи та рівності. У 1890-х рр. цю ідею використав у своїй теорії Ф. Тернер та експлікував іiі в есе «Роль фронтиру в американській історії», що яскраво свідчить про тяглість і спадкоємність ідей американського лідерства та винятковості. Т. Джефферсон, звертаючись до жителів Вашингтона 4 березня 1909 р., відводить своєму народові особливе місце серед інших, проте наголошує, що цей виклик є гідним та жахливим, адже США $є$ «єдиним пам'ятником прав людини і єдиним сховищем священного вогню свободи та самоврядування, який має бути запалений в інших регіонах Землі...» [3]. Цьому, як стверджував діяч, сприяє американська конституція, що увібрала в себе головні цінності вільної держави. У ХІХ ст. американський експансіонізм взяв концепцію «Імперії свободи» у якості ідеологічного базизу, який в наступні два століття став потужним інструментом зовнішньої політики Сполучених Штатів.

Погляди А. Гамільтона не були такими масштабними, як у Т. Джефферсона, його головного політичного опонента, проте думки Гамільтона щодо скерування зовнішньої політики країни мали аналогічне спрямування. Він стверджував, що «... респектабельність в очах іноземних держав не була метою, до якої ми [американці - авт.] прагнули; що належним об'єктом республіканського управління має бути внутрішній спокій і щастя. Це є очевидним протиріччям. Жоден уряд не міг надати нам спокою і щастя для нашого дому, якщо він не володів достатньою силою для забезпечення нашої респектабельності за кордоном» [1, p. 20]. Так само вважав і Т. Пейн, автор памфлету «Здоровий глузд», в якому він сформулював відому фразу: «справа Америки є, у більшій мірі, справою всього людства» [4], наголошуючи на тому, що Американська революція вже стала одним із поворотних моментів у світовій історії. Т. Пейн вірив в нову республіку як в ту, що за його словами має все необхідне, аби «заснувати цей світ від від самого початку». 
Важливу роль у процесі формулювання головних засад ведення Сполученими Штатами міжнародних справ відіграли погляди Дж. Вашингтона, виголошені першим президентом в інавгураційних промовах та відомому «Прощальному посланні». Дж. Вашингтон стверджував, що «немає жодного народу, якому варто було б визнати й піднести хвалу невидимій долоні, що керує справами людей, більшою мірою, аніж народу Сполучених Штатів» та наголошував на відповідальності за збереження свободи та республіканської моделі правління, що залежить від успіху експерименту, «ввіреному в руки американському народові» [5, с. 4]. Відповідно, роль держави та іiі представників сакралізується і набуває значення не тільки американського, але й загальнолюдського.

Таким чином, в останній третині XVIII ст. в американській свідомості поєдналися месіанські, духовно-релігійні, просвітницькі погляди та ідеали, які склали вагому частину ідеологічного базису зовнішньої політики Сполучених Штатів. Інтерсуб'єктивна природа ранніх концепцій зумовила їх стійкість у суспільстві, що посприяло створенню у подальші десятиліття потужного банку політичних ідей Америки. Цей складний ідеологічний комплекс був успішно інструменталізований та імплементований американським істеблішментом на початку XX, проголошеного «Американською добою» століття, яке ознаменувалося якісними трансформаціями у зовнішньополітичній думці країни, в основі якої до сьогодні залишаються глобальні інтереси та претензія на світову роль.

\section{Література:}

1. Tucker, R., Hendrickson, D. Empire of Liberty: The Statecraft of Thomas Jefferson. Oxford University Press, 1990. 360 p.

2. From Thomas Jefferson to George Rogers Clark, 25 December 1780 / National Archives. URL: https://founders.archives.gov/ documents/Jefferson/01-04-02-0295

3. Thomas Jefferson to the Citizens of Washington, D.C., 4 March 1809 / National Archives. URL: https://founders.archives.gov/ documents/Jefferson/03-01-02-0006

4. Paine, T. Common Sense. Philadelphia, 1776 / Project Gutenberg. URL: https://www.gutenberg.org/files/147/147-h/147-h.htm

5. Інавгураційні промови президентів США. Харків, 2009. 336 с. 